\title{
A review of pastoral research carried out on the West Coast of the South Island: $1960-2000$
}

\author{
J.D. MORTON ${ }^{1}$ and P.H. WILLIAMS ${ }^{2}$ \\ ${ }^{1}$ AgResearch Invermay, PB 50034, Mosgiel \\ ${ }^{2}$ Crop and Food Research Lincoln, PB 4704, Christchurch
}

jeff.morton@agresearch.co.nz

\begin{abstract}
The pastoral research carried out on the West Coast of the South Island between 1960 and 2000 could be divided into three categories; nutrient requirements for pasture, pasture establishment and growth and animal performance. Because of the varied fertility of the soil types present, research on nutrient requirement was the largest category. In the 1960's, requirements for pasture establishment and early growth on pakihi (podzol) soils of lime, phosphorus (P), elemental sulphur (S), potassium $(\mathrm{K})$, copper $(\mathrm{Cu})$ and molybdenum were identified. This work was extended to determine $\mathrm{P}, \mathrm{S}$ and $\mathrm{K}$ maintenance requirements of pakihi, recent alluvial and brown terrace soils in the 1970's and 1980's. Elemental S was shown to be the most cost effective $S$ fertiliser under annual rainfall greater than $2000 \mathrm{~mm}$ and the tetraphenyl boron (TBK) test was calibrated to measure the supply of nonexchangeable $\mathrm{K}$ on recent soils. A series of trials were carried out to determine pasture yield responses to fertiliser nitrogen (N) on recent soils in the early 1970's. Later work in the mid 1980's showed that measurement of accumulated soil and air temperature from early spring did not improve the accuracy in prediction of pasture yield responses to $\mathrm{N}$.
\end{abstract}

On the poorly drained, acid and infertile pakihi soils, the interactions between seed coating and lime were measured and the yield advantages of Maku Lotus and Yorkshire fog as alternative pasture species to ryegrass and white clover demonstrated. Rate of pasture growth trials determined the seasonal pattern of pasture production on a range of sites from 1970 to 1995. On recent soils that could not be moled, gravel moling and hump and hollowing substantially increased pasture production during a spring with high rainfall $(2000 \mathrm{~mm})$.

In the early 1980's, dairy grazing trials showed that lengthening the grazing rotation during autumn increased winter and spring pasture production. For sheep, preferential grazing of thin ewes from weaning to mating increased overall ovulation rate. The density of sheep dung patches was shown to increase with winter stocking intensity on a pakihi soil. Surveys of dairy farm practice established an association between effectiveness of magnesium $(\mathrm{Mg})$ supplementation of dairy cows and reducing the incidence of metabolic disorders. Many dose response trials established the requirement by dairy calves for selenium (Se), cobalt (Co) and $\mathrm{Cu}$ on different West Coast soils.

Close contact between West Coast scientists, advisors and farmers ensured that local research information was efficiently communicated with a resulting high level of farmer adoption.

Keywords: animal management, fertility, lime, nitrogen, pasture establishment, phosphorus, potassium, soils, South Island, sulphur, trace elements, West Coast

\section{Early research - pre 1960 to 1970}

Up to the 1960's, pastoral agriculture was confined to the recent alluvial and lower terrace soils because of their better fertility and drainage. Information on farming these soils was gained from some local observational trials and knowledge gained from farming similar soils in Nelson and Canterbury. Although attempts had been made to establish pasture on pakihi soils around Westport, these had largely failed due to a number of factors. The Cawthron Institute undertook research on pakihi soils at Sergeant Hill, near Westport between 1923 and 1939, with 450 ha developed to pasture (Chittenden 1964). The outbreak of war and shortage of labour together with pasture deterioration under the stock management practised caused the area to be abandoned. It was not until the early 1960's that Jim Bruce-Smith, Peter During and Ken McNaught used both visual assessment and pasture cutting in a series of factorial trials to establish the initial requirement for lime, $\mathrm{P}$, elemental $\mathrm{S}, \mathrm{K}, \mathrm{Cu}$, Mo and possibly zinc (Zn) for white clover establishment on the Addison gley podzol (McNaught et al. 1970; During \& Martin 1964). The need for elemental S was confirmed in a trial on an Okarito soil at Mawheraiti in the upper Grey Valley (Wright \& Morton 1976). Initial grazing $\mathrm{x}$ fertiliser trials at Bald Hill between 1964 and 1970 demonstrated the ability of pakihi to carry 7-12 sheep SU/ha without animal health problems provided that the animals were drenched with anthelmintic and $\mathrm{Cu}$ and cobalt (Co) (O'Connor \& Chunn 1968). Trials on other pakihi soils established that initial nutrient requirements were similar for other pakihi soils (O'Connor, unpublished results) and this was further confirmed by subtractive glasshouse pot trials (Smith $e t$ al. 1976). These trial results were used to formulate a pakihi starter fertiliser mix, still largely in use today. 
Research on soil nutrient requirements: 19701990

\section{Phosphorus}

With nutrient requirements for pasture establishment determined, attention now turned to maintenance nutrient requirements on pakihi soils. On an Addison soil at the Bald Hill Field Research Area near Westport, Grey Smith and others managed a 7-year sheep grazing trial to determine the interaction in pasture production and liveweight gain between rate of fertiliser (500 vs $1000 \mathrm{~kg} \mathrm{33 \%}$ potassic, reverted superphosphate/ha/yr) and stocking rate (11 vs 17 ewes/ha). Pasture dry matter (DM) production was increased by up to $30 \%$ by the high fertiliser rate at the high stocking rate, with a smaller fertiliser response at the lower stocking rate (Smith \& Chunn, 1973).

On the nearby Bald Hill Demonstration Farm (Morton \& Williams 1987), on a site with an initial soil Olsen P of $8 \mu \mathrm{g} /$ $\mathrm{ml}$, a linear pasture yield response up to $120 \mathrm{~kg} \mathrm{P} / \mathrm{ha} / \mathrm{yr}$ (mean Olsen P $14 \mu \mathrm{g} / \mathrm{ml}$ ) was measured under sheep

Figure 1 Relationship between relative pasture production and soil. Olsen $\mathrm{P} \bullet=$ Recent soil; $\mathrm{O}=$ Pakihi soil.

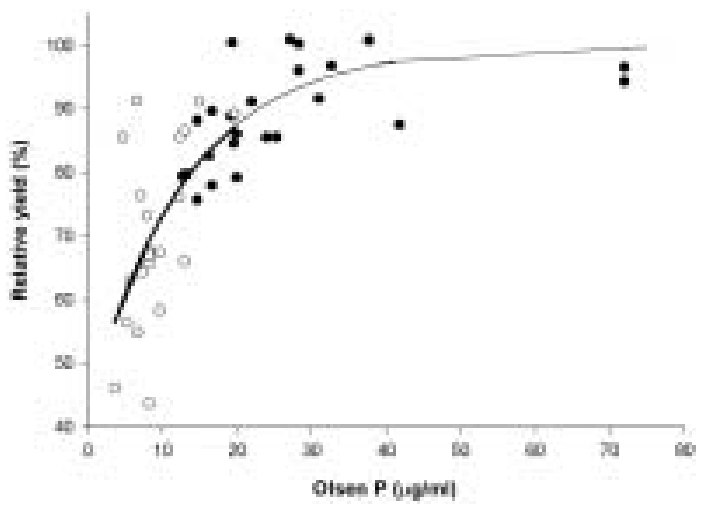

grazing over 4 years (Figure 1). On a recent soil in the Grey Valley (initial Olsen P $13 \mu \mathrm{g} / \mathrm{ml}$ ), there was a smaller pasture yield response up to $30 \mathrm{~kg} \mathrm{P} / \mathrm{ha} / \mathrm{yr}$.

\section{Phosphorus $x$ sulphur}

In the 1970's, soil Olsen P levels on dairy farms on recent soils were generally high $(40-50 \mu \mathrm{g} / \mathrm{ml})$ at moderate stocking rates of about 2 cows/ha and production of 400-500 kg milksolids/ha, because of greater than maintenance fertiliser $\mathrm{P}$ applications from split spring and autumn applications. Split applications were necessary to ensure a whole pasture growth season supply of S on low ASC soils under high annual rainfall
(2-4000 $\mathrm{mm}$ ) but also increased the rate of $\mathrm{P}$ applied. The hypothesis that a lower rate of sulphur superphosphate in the spring was a more cost effective fertiliser policy was tested in a 5-year trial at 3 sites (Williams \& Morton 1985).At Kowhitirangi, inland from Hokitika (initial Olsen P $25 \mu \mathrm{g} / \mathrm{ml}$, soil sulphate S 6 $\mathrm{ppm}$ ) with a mean annual rainfall of $3380 \mathrm{~mm}$, there was no pasture yield response to a single spring application

Table 1 Pasture yield responses ( $\mathrm{kg} \mathrm{DM} / \mathrm{ha}$ ) to superphosphate and elemental $\mathrm{S}$ (mean of 5 years).

\begin{tabular}{lllll}
\hline $\begin{array}{l}\text { Superphosphate } \\
(\mathrm{kg} / \mathrm{ha})\end{array}$ & \multicolumn{2}{c}{$\begin{array}{c}\text { Kowhitirangi } \\
\text { Elemental S } \\
(\mathrm{kg} / \mathrm{ha})\end{array}$} & \multicolumn{2}{c}{$\begin{array}{c}\text { Ikamatua } \\
\text { Elemental S } \\
(\mathrm{kg} / \mathrm{ha})\end{array}$} \\
\hline 0 & 0 & 50 & 0 & 50 \\
\hline 250 & 6890 & & 5040 & \\
375 & 7540 & 8000 & 6760 & 6670 \\
500 & 7610 & 7950 & 6570 & 6870 \\
625 & 7300 & 8240 & 6600 & 7090 \\
SED & 7520 & 8170 & 6930 & 7260 \\
Comparison 250+375 & 150 & 240 & 120 & 160 \\
vs 250+S +375+S & & $\mathrm{P}<0.01$ & & $\mathrm{P}>0.05$
\end{tabular}

of superphosphate but a significant response to superphosphate plus $50 \mathrm{~kg} / \mathrm{ha}$ of elemental S compared with superphosphate alone, averaged over all the rates (Table 1). In contrast at Ikamatua in the Grey Valley (Olsen P $12 \mu \mathrm{g} / \mathrm{ml}$, sulphate $\mathrm{S} 2 \mathrm{ppm}$ ) under a lower annual rainfall of $2020 \mathrm{~mm} / \mathrm{yr}$, there was a significant pasture yield response up to $625 \mathrm{~kg}$ superphosphate/ha/ yr but no significant response when elemental $\mathrm{S}$ was added to the superphosphate. From these trial results, farmers in areas with greater than $2000 \mathrm{~mm}$ annual rainfall were recommended to apply an appropriate maintenance rate of $22 \% \mathrm{~S}$ superphosphate in the spring. This mix is still widely used today. In areas with less than $2000 \mathrm{~mm}$ annual rainfall, $\mathrm{S}$ superphosphate was recommended where fertiliser was applied in autumn only on sheep and beef farms.

\section{Potassium}

The 1966-73 Bald Hill trial was followed by a 4-year study of techniques to measure the pasture and animal production response to $\mathrm{K}$ fertiliser on the same site (Morton 1981a). Under hogget grazing at 15/ ha during winter and 30/ha during summer, there was no significant response in pasture production (Figure 2) or liveweight gain above $50 \mathrm{~kg} \mathrm{KCl} / \mathrm{ha} / \mathrm{yr}$. In contrast, under mowing with both nil and $60 \%$ of clippings returned, there was a pasture production response up to $350 \mathrm{~kg} \mathrm{KCl} / \mathrm{ha} / \mathrm{yr}$. The lack of response to higher rates of $\mathrm{K}$ under grazing was attributed to efficient $\mathrm{K}$ cycling at a high stocking rate from the lateral spread of urine $\mathrm{K}$ on a soil with no vertical drainage. Infiltration rates on pakihi soils are low so urine patches spread sideways, allowing efficient 
Figure 2 Relationship between pasture production and potash application. ( $\bullet$, solid line) $=$ grazing trial; $(\square$, dotted line) = clippings returned; $(\square$, dashed line $)=$ clippings discarded. Lines/curves are fitted using data from years 2,3 and 4 .

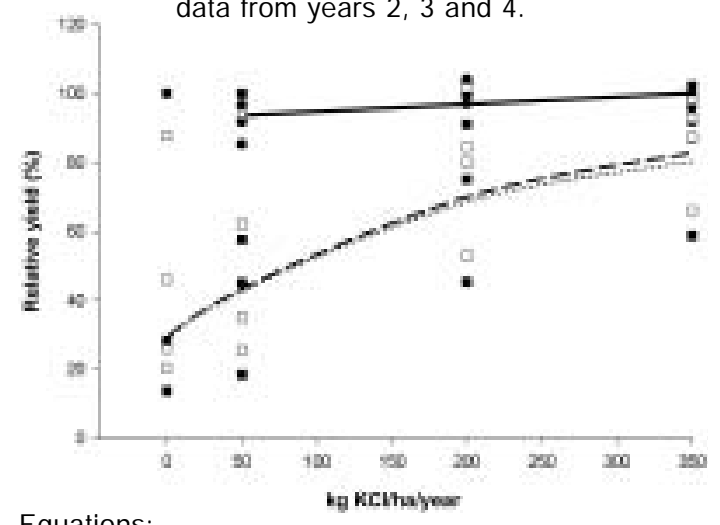

Equations:

Grazing RY $=92.51+.0218 * \mathrm{KCl} \quad r^{2}=0.136$.

Clippings returned $\mathrm{RY}=89.9-61.6 * 0.99471 \mathrm{KCl} \mathrm{r}^{2}=$ 0.537.

Clippings discarded $\mathrm{RY}=94.9-65.5 * 0.99511 \mathrm{KCl} \mathrm{r}^{2}=$ 0.655 .

recycling of K in urine by the pasture (Williams 1991).

A feature of West Coast recent soils was that because of the presence of clay minerals that supply and fix plantavailable K, soil K quick test (QT) levels remained in the low range regardless of rate of $\mathrm{K}$ application. To obtain a soil testing method to measure reserve $\mathrm{K}$ in these soils, a series of mowing trials with $60 \%$ clippings returned were carried out to establish a relationship between pasture production response to $\mathrm{K}$ and TBK- extractable K (Williams et al. 1986). Although only a moderately strong correlation was obtained (Figure 3), the TBK test has been widely used since on West Coast recent and other weakly weathered soils in New Zealand to give an indication of the K-supplying power of the soil and help prevent the unnecessary use of $\mathrm{K}$ fertiliser.

Figure 3 Correlation between relative yield and soil test TBK. Non responsive sites •; responsive sites 0 .

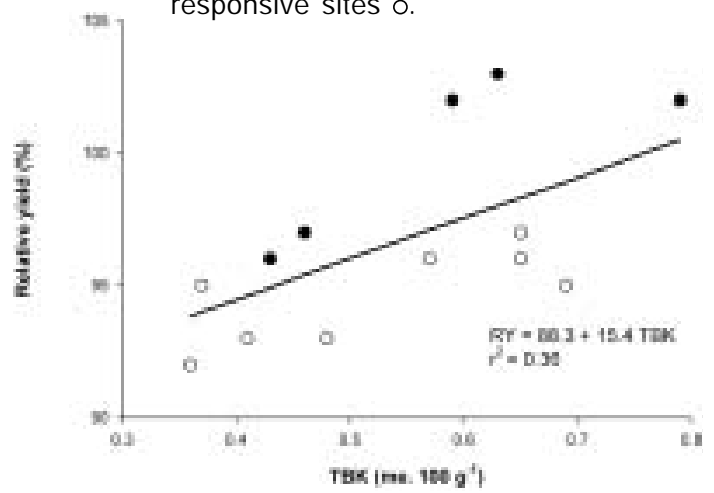

\section{Nitrogen}

As part of a National Series, pasture yield responses to $\mathrm{N}$ fertiliser were measured at Kowhitirangi and Springs Junction in the Maruia Valley in the spring and Kokatahi near Hokitika and Totara Flat in the Grey Valley in the autumn of 2 years (Williams \& Paterson 1983). There were significant pasture yield responses up to $100 \mathrm{~kg} \mathrm{~N} /$ ha but the efficiency of response diminished above 50 $\mathrm{kg} \mathrm{N} / \mathrm{ha}$. Best responses occurred in September/October (up to $22 \mathrm{~kg} \mathrm{DM} / \mathrm{kg} \mathrm{N}$ ) and March/April (up to $10 \mathrm{~kg}$ $\mathrm{DM} / \mathrm{kg} \mathrm{N}$ ). Pasture yield depressions were measured in weeks 13-15 after $\mathrm{N}$ was applied and were greater in October and at higher rates of $\mathrm{N}$. The proportion of clover in the sward declined with increasing rate of spring N.

Pasture yield responses to $\mathrm{N}$ in spring were compared with accumulated soil and air temperature after application on 6 dairy farm sites over 3 years (Morton et al. 1989), but the accuracy of prediction of the optimum time to apply $\mathrm{N}$ was not improved.

\section{Pasture establishment and growth Clover and grass establishment}

Pasture establishment by oversowing on acid, infertile pakihi soils was characterised by slow grass establishment. Delaying grass sowing until the autumn after spring clover establishment had no effect on grass yield in the second year (Morton \& Lister 1982). Coating grass seed with a lime reverted superphosphate/talc magnesite mix improved the establishment of ryegrass but not cocksfoot or timothy. High rates of lime (7.5 t/ ha) are used to establish pasture on pakihi soils, so the establishment of uncoated and lime coated clover seed was compared at 3 and $1 \mathrm{t}$ lime/ha to determine whether there was a need for coating (Wright \& Morton 1976). Clover seed coating had no effect on establishment or early production and there was no significant interaction between coating and rate of lime. However the uncoated clover seed had much greater rhizobium loadings than the lime coated seed.

The recommendations from this research were to continue with spring oversowing of coated clover and grass seed.

\section{Alternative pasture species}

Because of the high cost of the fertiliser and lime required for clover and ryegrass establishment on pakihi soils, it was considered that species more tolerant of low soil nutrient status and $\mathrm{pH}$ would be better suited. Trials conducted at Mawheraiti (Morton 1980) and Awatuna between Greymouth and Hokitika (Morton 1981b) showed that Maku Lotus and Massey Basyn Yorkshire fog were significantly $(\mathrm{P}<0.05)$ higher yielding at low rates of lime $(500 \mathrm{~kg} / \mathrm{ha})$ and $\mathrm{P}(40 \mathrm{~kg} / \mathrm{ha})$ than white 
clover and ryegrass but there was no significant difference in yield at $2 \mathrm{t}$ lime/ha and $100 \mathrm{~kg} \mathrm{P} / \mathrm{ha}$ (Table 2). The high cost of Maku Lotus seed and difficulties in keeping quality through grazing management prevented use of these alternative pasture species.

Table 2 Effect of lime and phosphate on mean DM yield $(\mathrm{kg} / \mathrm{ha}$ ) of two pasture types from second and third years after sowing.

\begin{tabular}{lll}
\hline $\begin{array}{l}\text { Lime } x \\
\text { phosphate } \\
(\mathrm{kg} / \mathrm{ha})\end{array}$ & $\begin{array}{l}\text { Pasture type } \\
\text { White clover/ }\end{array}$ & $\begin{array}{l}\text { Lotus/Yorkshire } \\
\text { fog }\end{array}$ \\
\hline $500 \mathrm{~L} / 20 \mathrm{P}$ & 980 & 2790 \\
$500 \mathrm{~L} / 80 \mathrm{P}$ & 1450 & 4020 \\
$2000 \mathrm{~L} / 20 \mathrm{P}$ & 2060 & 3050 \\
$2000 \mathrm{~L} / 80 \mathrm{P}$ & 3610 & 4380 \\
\hline
\end{tabular}

LSD (5\%) for horizontal comparisons 1660 .

LSD (5\%) for vertical comparisons 3260 .

\section{Pasture growth}

The seasonal distribution of pasture growth has been measured at Bald Hill (Radcliffe 1975), Kowhitirangi and Ahaura in the lower Grey Valley (Morton \& Paterson 1982), HariHari and Whataroa in South Westland (unpublished results) and 10 sites from Whataroa to Karamea (Davis et al. 1998). Generally the pattern of production was for low winter growth (3-15 $\mathrm{kg} \mathrm{DM} / \mathrm{ha} /$ day), increasing but variable spring pasture growth from September (15-50 $\mathrm{kg} \mathrm{DM} /$ ha/day) to peak in November (47-82 $\mathrm{kg} \mathrm{DM} / \mathrm{ha} /$ day), reliable summer growth (33-73 kg DM/ha/yr) with autumn growth decreasing from March (36-73 $\mathrm{kg} \mathrm{DM} / \mathrm{ha} /$ day) to a more variable rate by May (4-20 kg DM/ha/day). Although it is difficult to compare annual pasture production between sites because of different years of measurement and measurement technique, there was a trend for production to increase from South Westland (9-11 t DM/ha) to Westport/Karamea (14 t DM/ha), probably because of lower rainfall.

\section{Soil drainage}

Although not limited by soil texture or in many cases structure, soil drainage on many recent and especially gley recent soils was not fast enough to cope with the high intensity (up to $100 \mathrm{~mm} /$ day) and prolonged (up to $1000 \mathrm{~mm}$ per month with $90 \%$ raindays) rainfall, resulting in waterlogging, hoof damage and large reductions in pasture growth and utilisation. Because these soils had insufficient clay $(<10 \%)$ to hold moles, drainage was restricted to surface drains and more recently hump and hollows. At Kowhitirangi on a gley recent soil, gravel mole drainage where fine gravel was inserted into the slot to overcome the inability of the soil to hold moles and hump and hollowing was compared with no drainage under dairy cow grazing over 3 years (Francis \& Morton
1991). Only in 1988/89 where $1011 \mathrm{~mm}$ fell in 29 raindays in October and $3824 \mathrm{~mm}$ was measured from October to May was there a significant $(\mathrm{P}<0.05)$ pasture yield advantage (24\%) from gravel mole drainage and hump and hollowing over control. The high cost of gravel mole drainage $(\$ 3000 / \mathrm{ha})$ has precluded its more widespread use and hump and hollowing has become the preferred drainage technique on these soils.

\section{Animal production \\ Dairy}

Poor feeding in early spring plus wet and cold climatic conditions led to high incidences of metabolic disorders (up to 20\%) on West Coast dairy farms. Following the work of Mike O'Connor and co-workers in the Waikato, farm surveys carried out from 1979 to 1981 showed that higher cow serum Mg levels were associated with more effective $\mathrm{Mg}$ supplementation to cows (higher rates of $\mathrm{Mg}$ fed and drenching and addition to hay and silage rather than trough treatment and dusting) and also higher feeding levels before and after calving (Morton 1982). These findings were widely adopted by dairy farmers with a subsequent reduction in the incidence of metabolic disorders.

In the 1980's, per cow and ha milk production on dairy farms was limited by lack of pasture supply at calving. Over 3 years, Williams (1984) studied the effect of autumn and winter grazing management on two farms and reported that lengthening the autumn grazing rotation from 28 to $35-49$ days resulted in up to a $40 \%$ increase in autumn and winter pasture production (Table 3). This management allowed much higher pasture covers to be available at calving and was adopted

Table 3 Effect of short and long autumn rotations on pasture production ( $\mathrm{kg} \mathrm{DM} / \mathrm{ha}$ ) - mean of 3 years for autumn and 2 years for other seasons.

\begin{tabular}{lllll}
\hline Site & \multicolumn{2}{c}{ Kowhitirangi } & \multicolumn{2}{c}{ Hari Hari } \\
Rotation length (days) & 28 & $35 / 49$ & 28 & $35 / 49$ \\
\hline Autumn & 800 & 1440 & 1560 & 2080 \\
Winter & 495 & 925 & 780 & 1425 \\
Spring/summer & 4330 & 4125 & 6510 & 6225 \\
\hline
\end{tabular}

by a high proportion of West Coast dairy farmers.

From 1969 to 1975,22 trials with dairy calves were carried out to measure liveweight responses to Se and $\mathrm{Cu}$ (Morton 1981c). There were significant responses to Se on recent $(\mathrm{P}<0.01)$ and sand $(\mathrm{P}<0.1)$ soils but not on brown terrace soils. For $\mathrm{Cu}$, there were no significant responses on recent soils but a greater demand for $\mathrm{Cu}$ from more animals carried plus further depletion of soil $\mathrm{Cu}$ reserves since then, have resulted in low animal $\mathrm{Cu}$ levels. 


\section{Sheep}

In the 1970's and 1980's there were about 500,000 sheep on the West Coast but these numbers have declined greatly since because of conversion of sheep farms to dairy. On most sheep farms at that time, production was low with average lambing percentages of about $100 \%$ and many light $13 \mathrm{~kg}$ carcass weight lambs sold as late as May. Ewe condition at weaning was often low with much variation between animals because of poor feeding of twin-bearing ewes in the spring. Summer pasture growth was usually abundant but pasture quality could be low because stocking rate was too low to utilise the available feed. A grazing trial at Coal Creek near Greymouth demonstrated that preferentially feeding thin ewes on the best quality pasture from weaning to mating and using the fatter ewes to follow-up resulted in a more even spread of ewe condition and liveweight at mating and a higher ovulation rate and wool production compared with grazing all the ewes in one mob (Morton 1992) (Table 4). Although not widely adopted by West Coast sheep farmers, in other areas condition scoring of ewes at weaning is becoming more common.

Table 4 Effect of ewe condition and feeding on ewe ovulation rate at the start of mating and wool production and wool production ( $\mathrm{kg} / \mathrm{ewe}$ ) from weaning to mating (mean of 2 years).

\begin{tabular}{llcc}
\hline $\begin{array}{l}\text { Ewe condition } \\
\text { at weaning }\end{array}$ & $\begin{array}{l}\text { Feeding from } \\
\text { weaning to mating }\end{array}$ & $\begin{array}{c}\text { Ovulation } \\
\text { rate }\end{array}$ & $\begin{array}{c}\text { Wool } \\
\text { production }\end{array}$ \\
\hline Thin & Preferential & 1.35 & 1.01 \\
Thin & Follow-up & 1.01 & 0.82 \\
Fat & Preferential & 1.44 & 1.11 \\
Fat & Follow-up & 1.21 & 0.91 \\
LSD (5\%) & & 0.20 & 0.19 \\
\hline
\end{tabular}

Block grazing of ewes during winter can be carried out with shifts ranging from one to four days. One of the advantages of daily shifts is a more even spread of sheep dung and urine over the grazed area because of less opportunity for camping, allowing more efficient cycling of nutrients in excreta. Another trial at Coal Creek proved this hypothesis with significantly greater $(\mathrm{P}<0.05)$ clumping of dung patches from a stocking density of 1800 sheep/ha/day when shifted every 4 days compared with daily (Morton \& Baird 1990).

Trace element response trials were also carried out with lambs from 1962-73 at 17 sites. There were no significant liveweight gain responses to $\mathrm{Se}, \mathrm{Co}$ or $\mathrm{Cu}$ measured. Later work on pakihi and terrace soils showed that initial application of cobalt and copper sulphate at sowing maintained blood serum and liver vitamin $\mathrm{B}_{12}$ and $\mathrm{Cu}$ levels in the adequate range for up to 8 years (Morton 1986).

Because of the wet, mild conditions, internal parasites were a problem for growth of young sheep. From 1969 to 1976 , in ten of eleven trials there were significant responses in hogget liveweight gain and wool weight to drenching with anthelmintics (Morton 1981d).

\section{Conclusions}

Most of the research on the West Coast was carried out while there were District Scientists based there from 1970-1990. During that time, achievements included:

1. Developed and confirmed maintenance nutrient requirements for pastures

2. Introduced the TBK soil test to measure nonexchangeable $\mathrm{K}$

3. Identified the role for Lotus/Yorkshire fog on pakihi soils

4. Tested new drainage techniques

5. Quantified the effect of dairy autumn grazing management

6. Proved the effectiveness of $\mathrm{Mg}$ supplementation of dairy cows

7. Demonstrated the usefulness of preferential summer grazing of thin ewes

Because this research was carried out on local farms by local science staff who farmers identified with, farmer adoption was very high.

\section{ACKNOWLEDGEMENTS}

The authors acknowledge the efforts of several other scientists on the West Coast including Peter During, Mike O'Connor, Grey Smith, Geoff Mew, Craig Ross and also the technical assistance of many, especially Chris Chunn who worked there for a long period. Thanks also to consultants such as Don Kennedy, Mike Gould, Dave Wright, John Dawson, Peter Brierley, Elton Merrin, and Mike Wheadon plus many others who gave encouragement and helped transfer the information. Greatest thanks go toWest Coast farmers whose thirst for knowledge, willingness to try new ideas, and cheerfulness and good humour in the face of some adverse climatic and economic factors made the West Coast such an enjoyable place for us to live and practice research.

\section{REFERENCES}

Chittenden, E.T. 1964. A review of the Cawthorn Institute's work on pasture development of pakihi lands. Proceedings of the New Zealand Grassland Association 26: 50-56.

Davis, K. L.; Thomson, N.A.; McLean, N.R.; McCallum, D.A.; Hainsworth, R. J.; Wards, A.J.; Barton, R. G. 1998. Pasture growth on dairy farms in the Golden Bay and West Coast of the South Island. Proceedings of the New Zealand Grassland Association 60: 9-14. 
During, C.; Martin, D. J. 1968. Sulphate nutrition, movement and sorption, with special reference to a gley podzol, West Coast, South Island. New Zealand Journal of Agricultural Research 11: 665-676.

Francis G. S.; Morton J. D. 1991. Effect of gravel mole drainage on soil physical properties and pasture production of a gleyed recent soil, West Coast, South Island, New Zealand. New Zealand Journal of Agricultural Research 34:317-324.

McNaught,K.J.; During, C. 1970. Relations between nutrient concentrations in plant tissues and responses of white clover to fertilisers on a gley podzol near Westport. New Zealand Journal of Agricultural Research 13: 567-590.

Morton J. D. 1980. Effect of lime and phosphate on lotus and white clover establishment and yield on Pakihi soils. New Zealand Journal of Experimental Agriculture 8(3/4): 231-233.

Morton, J. D. 1981a. Influence of trial management on pasture response to potassium on a pakihi soil. New Zealand Journal of Experimental Agriculture 9: 123127.

Morton J. D. 1981b. The effect of lime, phosphate and potassium on the growth of white clover and lotus based pastures on pakihi soils. Proceedings of the New Zealand Grassland Association 42:123 130.

Morton, J. D. 1981c. The effect of trace elements on stock live weight gain on West Coast soils. New Zealand Journal of Experimental Agriculture 9(2):135 140.

Morton, J. D. 1981d. Effect on live weight gain and fleece weight of anthelmintic drenching of hoggets on the West Coast. New Zealand Journal of Experimental Agriculture 9(2):123-127.

Morton, J. D. 1982. The importance of magnesium in West Coast dairying. Proceedings of the West Coast Dairy Farmers' Conference:1-13.

Morton J. D., Paterson D. J. 1982. Seasonal distribution of pasture production in New Zealand XVII. Kowhitirangi and Ahaura, West Coast, South Island. New Zealand Journal of Experimental Agriculture 10: 245-252.

Morton J. D.; Lister A. J. 1982. Establishment of grasses on West Coast Pakihi soils. New Zealand Journal of Experimental Agriculture 10(1):37-41.

Morton J. D. 1985. Effect of seed coating on establishment and yield of grasses on a West Coast pakihi soil. New Zealand Journal of Experimental Agriculture 13:403-405.

Morton J. D. 1986. Vitamin B12 and copper in blood serum and liver in hoggets in relation to cobalt and copper status of West Coast South Island soils and pastures. New Zealand Journal of Experimental Agriculture 14): 485-489.

Morton J. D.; Williams P. H. 1987. Phosphorous requirements of grazed pasture on pakihi and recent soils of the South Island west coast. New Zealand Journal of Experimental Agriculture 15: 277-282.

Morton J. D.; Francis S. M.; Swaine C. M. 1989. The use of accumulated temperature predictive systems for timing of spring nitrogen application. Proceedings of the Massey University Workshop: Nitrogen in N.Z. Agriculture and Horticulture:251-260.

Morton J. D.; Baird D. B. 1990. Spatial distribution of dung patches under sheep grazing. New Zealand Journal of Agricultural Research 33:285-294.

Morton J. D. 1992: Management of poor quality pastures for maximum animal performance during summer. Proceedings of the New Zealand Grassland Association 54:85-89.

O'Connor, M.B; Chunn C.J. 1968. Rates of fertiliser x rates of stocking trials. Research in the New Zealand Department of Agriculture. Annual Report of Research Division 1967-1968: 125.

Radcliffe, J.E. 1975. Seasonal distribution of pasture production in New Zealand. IV. Westport and Motueka. New Zealand Journal of Experimental Agriculture 3: 239-247.

Smith, R. G; Chunn, C .J. 1973. Rates of fertiliser and rates of stocking trials. Agricultural Research in the New Zealand Ministry of Agriculture and Fisheries 1972/73. Annual Report of the Research Division: 132133.

Smith, G.S.; Middleton, K.R.; Smith, R.G. 1976. Diagnosis of multiple plant-nutrient deficiencies in soils of the west coast of the South Island. I. "Pakihi" soils. New Zealand Journal of Experimental Agriculture 4: 423-428.

Williams, P.H.; Paterson D.J. 1983. Response of pastures to nitrogen fertiliser applied in autumn and spring on the West Coast of the South Island, New Zealand: New Zealand Journal of Experimental Agriculture 11: 247-250.

Williams P. H.; Morton J D 1985. Pasture responses to superphosphate and elemental sulphur on soils of the West Coast, South Island. New Zealand Journal of Experimental Agriculture 13: 369-374.

Williams, P. H. 1991. Potassium fertiliser requirements for West Coast dairy farms. Proceedings of the West Coast Farmers' Conference: 84-88.

Williams P. H.; Morton J. D.; Jackson B. L. J. 1986. Chemical soil test prediction of pasture responses to potassium on recent soils of the South Island west coast. New Zealand Journal of Experimental Agriculture 14: 411-416.

Wright D. B.; Morton J. D. 1976. Agricultural development of Pakihi soils on the West Coast. Proceedings of the New Zealand Grassland Association 38:19-30.

Williams, P.H. 1984. Autumn - a critical period for managing pastures. Proceedings of the West Coast Dairy Farmers' Conference: 29-32. 